\title{
Evaluating Daylight Factor Standard through Climate Based Daylight Simulations and Overheating Regulations in Estonia
}

\author{
Francesco De Luca, Martin Kiil, Raimo Simson, Jarek Kurnitski, Rein Murula \\ Tallinn University of Technology, Tallinn, Estonia
}

\begin{abstract}
Building interiors daylighting is a crucial aspect for occupant comfort and energy efficiency. Standards and requirements exist to guarantee minimum levels of natural illumination in new buildings on the basis of different metrics. Some rely only on interiors static characteristics, others additionally take into account location climate. The main aim of the present study is to investigate the validity of the static Daylight Factor (DF) requirement of the Estonian daylight standard against more reliable climatebased daylight simulations using the approved method Spatial Daylight Autonomy. Results show the weakness of DF in predicting appropriate daylight availability of building interiors for the city of Tallinn. Evaluations of DF in relation to overheating regulation is also presented.
\end{abstract}

\section{Introduction}

Daylight is the most appreciated source of illumination for building interiors of every typology for its capacity to render surfaces and objects without altering colours, to create contrasts which generate architecture quality and to be diffused in depth into the floor plan (Johnsen and Watkins, 2010). In commercial, office or school buildings daylight is particularly useful because its availability mostly coincides with the hours during which buildings are used (Reinhart, 2014). Additionally, daylight variability during days and seasons and day-night cycles improve well-being of occupants and their circadian rhythm (Lockley, 2009). In schools, the use of daylight through windows and skylight proved to be associated with improved student learning performances (Heschong, 2002). Window to Wall Ratio of minimum $20 \%$ proved to be the most significant daylight feature in school buildings for the improvement of student tests performance (Annesi and Annesi-Maesano, 2016).

Different methodologies exist to predict building interiors daylight levels, such as use of models and formulas or more reliable computer simulations (Reinhart and Lo Verso, 2010). Daylight Factor (DF) is a long-standing metric which estimates the potential natural illumination of an interior point as a percentage of the illuminance of an unobstructed point on the exterior of the room (Waldram, 1923). DF takes into account room size and layout, windows size and position, external obstructions, materials reflectance and glazing transparency. DF is an efficient metric due to its simple calculation method fast to perform through computer simulations. The limitation of DF calculation lies in not taking into account building location climate and orientation. In recent years researchers developed new climate based annual daylight metrics to predict accurately the quantity of illuminance and daylight autonomy in relation to threshold values (Reinhart et al., 2006; Nabil and Mardaljevic, 2006). Spatial Daylight Autonomy (sDA) is a recently developed climate-based metric used for the evaluation of daylight potentiality of different workplace environments such as offices and classrooms through dynamic simulations (Illuminating Engineering Society, 2013). sDA, taking into account location climate and room window orientation in addition to all the parameters used by DF, estimates the floor area ratio of a room that will receive, solely by daylight, the minimum illuminance required for at least $50 \%$ of the operating hours during the entire year. Together with sDA, Annual Sunlight Exposure (ASE) metric is defined. ASE estimates the floor area ratio which exceeds fixed amount of illuminance and operating hours during the entire year. The maximum floor area ratio allowed by ASE is $10 \%$. ASE is introduced to balance daylight availability and risk of glare in case of excessive direct solar access of building interiors.

In Estonia the standard "Daylight in dwellings and offices" set the required daylight in interiors using minimum mean Daylight Factor (mDF) values for different building typologies (Estonian Centre for Standardization, 2015). For school classroom it is required an $\mathrm{mDF}$ of minimum $2 \%$. Though being positive for occupant comfort daylight can generate solar gains that harm building energy efficiency due to increased cooling energy demand also at northern latitudes (Voll et al., 2016a). To improve building energy efficiency the Estonian regulation "Minimum Requirements for Energy Performance" sets the maximum internal temperature in degree-hour that different typology of buildings cannot exceed for different periods of the year (Estonian Government, 2019a). Recent developed studies investigate the relation of the two conflicting regulations and develop optimal solutions for building envelope and urban design (De Luca et al., 2018; Voll et al., 2016b).

The present study investigates if the minimum quantity of $\mathrm{mDF} 2 \%$ required by the Estonian standard guarantees proper level of interiors daylight through climate-based simulations, using the metric sDA. At the same time overheating analysis is performed to evaluate the relation between daylight standard and energy efficiency requirements in Estonia, together with ASE analysis for 
glare risk potentialities. The research presents an original contribution inasmuch still few studies evaluate reliability of DF metric and none yet in relation to Estonian climate and regulations. The present study is part of a larger research about design methodologies for school buildings in Estonia, thus school classroom is used as room type for the case study.

\section{Methods}

The single-sided window classroom model has a height of $3 \mathrm{~m}$ and a wall thickness of $0.5 \mathrm{~m}$ (Figure 1). A large number of classroom variations are generated through a parametric model. The room variations are different for width and depth, number and size of windows, orientations, window glass Visible Transmittance (VT), and presence of shading.

\section{Room parametric model}

The parametric model combines all the room depths, widths and orientations on the basis of 2 room types different for glazing Visible Transmittance and use of shading, excluding same combinations of north orientation for a total of 175 (Table 1).

Table 1: Room parameters used for the simulations.

\begin{tabular}{|c|c|c|c|c|c|}
\hline Type & $\begin{array}{c}\text { Room } \\
\mathbf{d}(\mathbf{m})\end{array}$ & $\begin{array}{c}\text { Room } \\
\mathbf{w}(\mathbf{m})\end{array}$ & $\begin{array}{c}\text { Orien } \\
\text { tation }\end{array}$ & $\begin{array}{c}\text { Glazing } \\
\text { VT(\%) }\end{array}$ & $\begin{array}{c}\text { Shading } \\
\mathbf{0 . 9 m}\end{array}$ \\
\hline \multirow{4}{*}{1} & 5 & 5 & South & 0.635 & No \\
\cline { 2 - 6 } & 6 & 6 & East & 0.635 & No \\
\cline { 2 - 6 } & 7 & 7 & North & 0.733 & No \\
\cline { 2 - 6 } & 8 & 8 & West & 0.635 & No \\
\cline { 2 - 6 } & 9 & 9 & \multicolumn{4}{|l}{} \\
\hline \multirow{4}{*}{2} & 5 & 5 & South & 0.635 & Yes \\
\cline { 2 - 6 } & 6 & 6 & East & 0.707 & Yes \\
\cline { 2 - 6 } & 7 & 7 & North & 0.733 & No \\
\cline { 2 - 6 } & 8 & 8 & West & 0.707 & Yes \\
\cline { 2 - 6 } & 9 & 9 & & & \\
\hline
\end{tabular}

Same room sizes for depth and width are used. The widths of $5 \mathrm{~m}, 6 \mathrm{~m}, 7 \mathrm{~m}, 8 \mathrm{~m}$ and $9 \mathrm{~m}$ are characterized by different quantity and size of windows, respectively by 2 of width and height $1.9 \times 1.7 \mathrm{~m}$ (WWR $45.6 \%$ ), 3 of $1.466 \times 1.7 \mathrm{~m}$ (WWR $41.5 \%$ ), 3 of $1.8 \times 1.7 \mathrm{~m}$ (WWR $43.7 \%$ ), 4 of $1.45 \times 1.7 \mathrm{~m}$ (WWR $41.1 \%$ ) and 4 of $1.7 \times 1.7 \mathrm{~m}$ (WWR $42.8 \%$ ). VT values and shading are assigned selectively to the room combinations for depth, width, and orientation with the scope to obtain classrooms which fulfil the Estonian maximum internal temperature requirement (Figure 2).

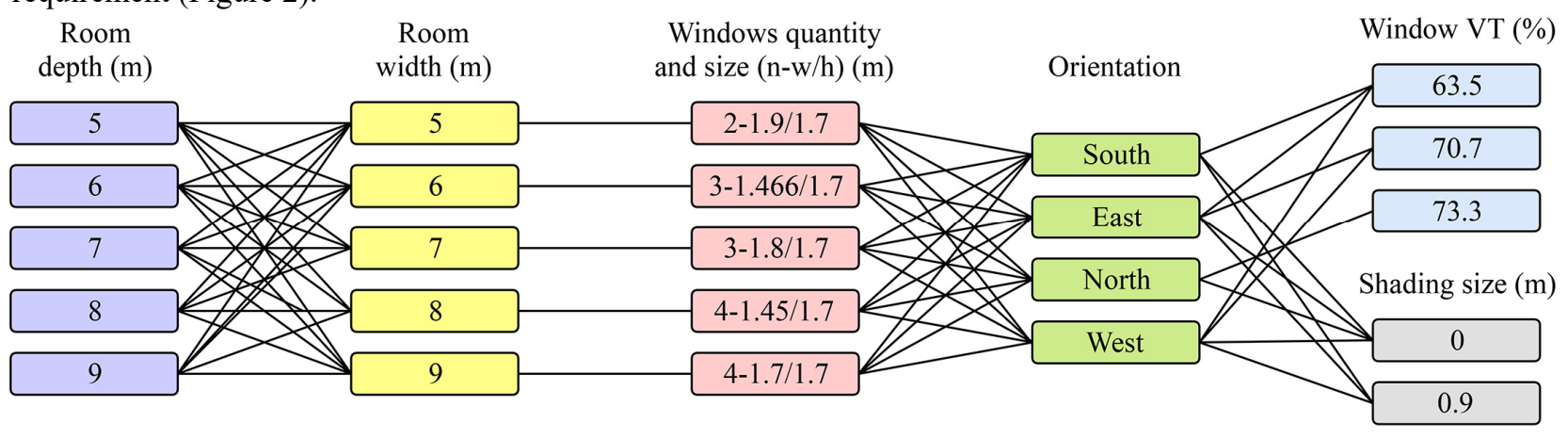

Figure 2: Diagram of room parameter combinations.

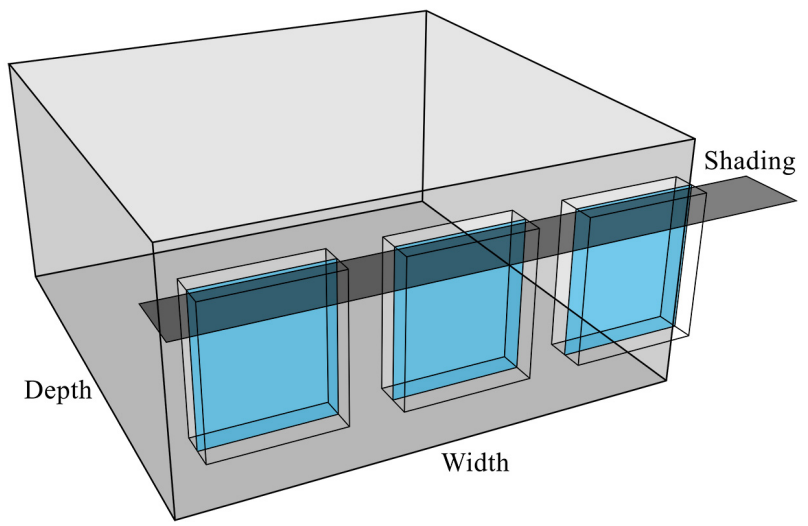

Figure 1: Room used in the study.

Windows have frame size of $5 \mathrm{~cm}$ except the operable one with frame of $15 \mathrm{~cm}$. The shading is a horizontal element located $10 \mathrm{~cm}$ above the windows. The parametric model, realized through the software Grasshopper for Rhinoceros (McNeel, 2019), integrates room parameters with daylight analysis and automation tools to run all the room variation simulations automatically and export result data.

\section{Daylight Factor analysis model}

Reflectance $(R)$ values are assigned to the elements of the parametric model walls, floor, ceiling and shading. For interiors daylight assessment regulations recommend standard conservative reflectance values. In addition, for the present study improved reflectance values are also used to obtain a larger number of combinations, for a total of 350, and perform simulations using real case reflectance parameters (Table 2).

Table 2: Standard/improved material reflectance values.

\begin{tabular}{|c|c|c|c|c|c|}
\hline & Walls & Floor & Ceiling & Shading & Ground \\
\hline $\mathbf{R}$ & $50 / 70$ & $20 / 40$ & $70 / 80$ & 35 & 20 \\
\hline
\end{tabular}

No surrounding buildings are modeled due to open areas locations of majority of new schools. The presented glazing VT values are used in the DF model. The validated daylight simulation software used is Radiance (Ward, 1994). The simulation grid is made of $20 \mathrm{~cm}$ cells for $80 \%$ of the floor, i.e. the regularly occupied area as suggested by BREEAM and LEED, and is located at $0.75 \mathrm{~m}$ height (Figure 3 and 4). The main Radiance parameters used are: -aa .1 -ab 5 -ad 1024 -ar 256. The CIE overcast sky model is used in the simulations. 


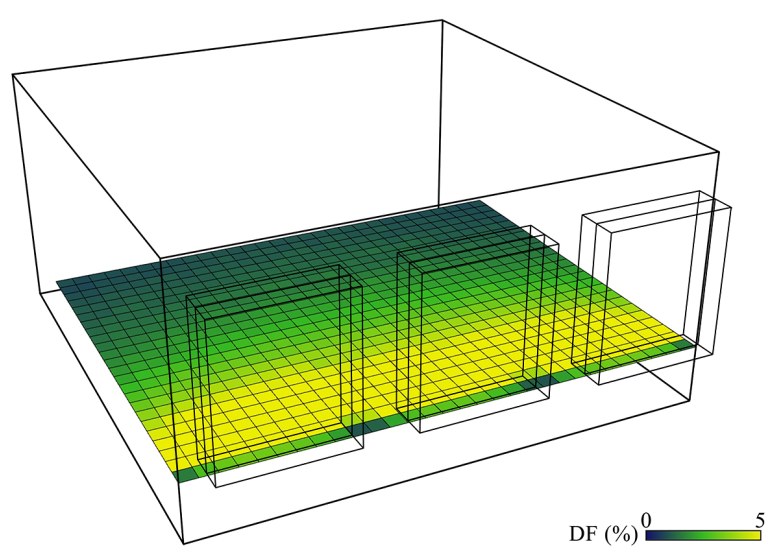

Figure 3: Room with Daylight Factor analysis grid.

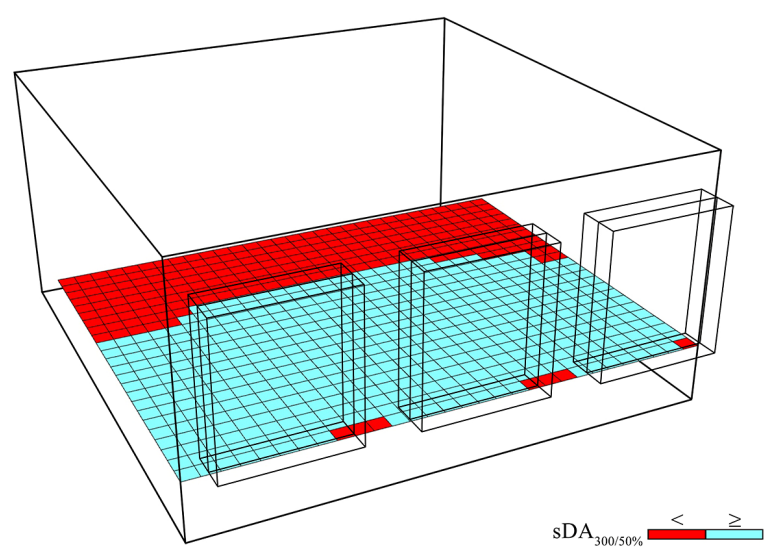

Figure 4: Room with Spatial Daylight Autonomy grid.

\section{Daylight annual climate-based simulation model}

The parametric model provides room elements different for every variation. Daylight annual dynamic simulation model uses the same reflectance (R) and Visible Transmittance (VT) values as Daylight Factor analysis.

Statistical weather data of the city of Tallinn from epw (EnergyPlusWeather) file 260380-TALLIN-HARKU-2014 are used. Annual daylight simulations are performed using the software Daysim that iterates Radiance simulations using daylight coefficients for a variety of sky conditions on the basis of the statistical weather data (Reinhart and Walkenhorst 2001). The occupancy schedule used is school year (01.09-15.06) Monday to Friday $8 \mathrm{am}-4 \mathrm{pm}$. The output of annual dynamic simulations is the daylight autonomy, i.e. the percentage of time during which the interior required illuminance is provided by daylight, using different metrics.

For the present study the sDA and ASE thresholds used are those of the approved method IES LM-83-12 (Illuminating Engineering Society, 2013). The room is considered well daylit if at least $55 \%$ of regularly occupied area receive $3001 x$ for at least $50 \%$ of operating hours $\left(\mathrm{sDA}_{300 / 50 \%}\right)$ (Figure 4 ), and if no more than $10 \%$ receives 1000lx for more than 250 hours ( $\mathrm{ASE}_{1000,250}$ ).

Daylight Factor and annual climate-based simulations are integrated in the parametric model through DIVA4, a Grasshopper environmental and daylight design plug-in (Solemma, 2019).

\section{Overheating simulation model}

Dynamic simulation software IDA-ICE v4.8 is used for overheating calculations (EQUA, 2019). Key parameters for simulations are given in Table 3 (Estonian Government, 2019b). Educational building maximum overheating is $100{ }^{\circ} \mathrm{C} \cdot \mathrm{h}$ for test period $1^{\text {st }}$ of May- $15^{\text {th }}$ of June and $15^{\text {th }}$ of August- $30^{\text {th }}$ of September.

\section{Results}

Daylight and overheating simulation results are presented. Daylight simulation results are used to evaluate through reliable dynamic annual daylight simulations if the minimum $\mathrm{mDF}$ of $2 \%$ required by the Estonian standard guarantees adequate interiors illuminance. Overheating simulation results are used to evaluate relation of $\mathrm{mDF}$ values and the Estonian interior temperature requirement.

Table 3. Overheating simulations parameters.

\begin{tabular}{|c|c|}
\hline \multicolumn{2}{|c|}{ Envelope \& thermal comfort parameter } \\
\hline Parameter & Value \\
\hline $\begin{array}{c}\text { External wall } \\
\text { (precast concrete element) }\end{array}$ & $\begin{array}{c}\text { Concrete } 150 \mathrm{~mm} \\
\text { Exp. polystyrene } 300 \mathrm{~mm} \\
\text { Concrete } 50 \mathrm{~mm} \\
\mathrm{U}_{\text {total }} 0,129\left[\mathrm{~W} /\left(\mathrm{m}^{2} \cdot \mathrm{K}\right)\right]\end{array}$ \\
\hline Windows - no shading & $\begin{array}{c}\mathrm{g} 0.35 ; \mathrm{U}_{\mathrm{g}} 0.58\left[\mathrm{~W} /\left(\mathrm{m}^{2} \cdot \mathrm{K}\right)\right] \\
\mathrm{U}_{\text {total }} 0.60\left[\mathrm{~W} /\left(\mathrm{m}^{2} \cdot \mathrm{K}\right)\right] ; \text { frame } \\
\text { rate } 0.034(\text { east, west, south) } \\
\quad \mathrm{g}-0.54 ; \mathrm{U}_{\mathrm{g}}-0.61 \\
\quad\left[\mathrm{~W} /\left(\mathrm{m}^{2} \cdot \mathrm{K}\right)\right] ; \\
\text { Utotal }-0.62\left[\mathrm{~W} /\left(\mathrm{m}^{2} \cdot \mathrm{K}\right)\right] ; \\
\text { frame rate } 0.034(\text { north })\end{array}$ \\
\hline Windows - shading & $\begin{array}{l}\mathrm{g} 0.42 ; \mathrm{Ug}_{\mathrm{g}} 0.70\left[\mathrm{~W} /\left(\mathrm{m}^{2} \cdot \mathrm{K}\right)\right] \\
\mathrm{U}_{\text {total }} 0.71\left[\mathrm{~W} /\left(\mathrm{m}^{2} \cdot \mathrm{K}\right)\right] ; \text { frame } \\
\quad \text { rate } 0.034(\text { east, west })\end{array}$ \\
\hline $\begin{array}{c}\text { External windows } \\
\text { perimeter thermal bridge }\end{array}$ & $0.1[\mathrm{~W} /(\mathrm{m} \cdot \mathrm{K})]$ \\
\hline Fixed infiltration & $1.5 \mathrm{~m}^{3} /\left(\mathrm{h} \cdot \mathrm{m}^{2, \text { external surface }}\right)$ \\
\hline Heating setpoint & $+21\left({ }^{\circ} \mathrm{C}\right)$ \\
\hline Cooling setpoint & $+25\left({ }^{\circ} \mathrm{C}\right)$ \\
\hline Supply air temperature & $>+16\left({ }^{\circ} \mathrm{C}\right)$ (without cooling) \\
\hline Air exchange rate & $4.2\left[1 /\left(\mathrm{s} \cdot \mathrm{m}^{2}\right)\right], \mathrm{CAV}$ \\
\hline \multicolumn{2}{|c|}{ Internal heat gains values } \\
\hline Internal heat gains & Value \\
\hline Occupant & $\begin{array}{c}14.0\left(\mathrm{~W} / \mathrm{m}^{2}\right) \\
\text { Activity level } 1.0(\mathrm{MET}) \\
\text { Clothing } 0.85 \pm 0.25(\mathrm{CLO})\end{array}$ \\
\hline Lighting & $5.0\left(\mathrm{~W} / \mathrm{m}^{2}\right)$ \\
\hline Equipment & $12.0\left(\mathrm{~W} / \mathrm{m}^{2}\right)$ \\
\hline \multicolumn{2}{|c|}{ Time schedule rules } \\
\hline Schedule & Rule (smoothing factor 0 ) \\
\hline Ventilation & $\begin{array}{l}00: 00-07: 00-0.0 \\
07: 00-17: 00-1.0 \\
17: 00-00: 00-0.0\end{array}$ \\
\hline Internal gains & $\begin{array}{l}00: 00-08: 00-0.0 \\
08: 00-12: 00-0.8 \\
12: 00-13: 00-0.5 \\
13: 00-16: 00-0.8 \\
16: 00-00: 00-1.0\end{array}$ \\
\hline
\end{tabular}




\section{Daylight Factor simulation results}

Being Daylight Factor not dependent on room orientation, results are grouped for glazing VT and use of shading. All room variations without shading fulfil the $\mathrm{mDF} \geq 2 \%$. Minimum and maximum values are presented in Table 4.

For variations with shading, with VT $63.5 \%$ (south) and with standard materials $\mathrm{mDF}$ requirement is fulfilled by all variations with room depth $5 \mathrm{~m}$ and by variations $5 \times 6 \mathrm{~m}, 7 \times 6 \mathrm{~m}$ and $9 \times 6 \mathrm{~m}$ (width $\mathrm{x}$ depth). With improved reflectance materials $\mathrm{mDF}$ is fulfilled by all variations with depth $5 \mathrm{~m}, 6 \mathrm{~m}, 7 \mathrm{~m}, 8 \mathrm{~m}$ except $6 \times 8 \mathrm{~m}$ and $8 \times 8 \mathrm{~m}$, and $9 \mathrm{~m}$. For variations with VT $70.7 \%$ (east and west) and standard materials $\mathrm{mDF}$ is fulfilled by all variations with room depth $5 \mathrm{~m}, 6 \mathrm{~m}$, and $7 \mathrm{~m}$ except cases $6 \times 7 \mathrm{~m}$ and $8 \times 7 \mathrm{~m}$. With improved reflectance materials $\mathrm{mDF}$ is fulfilled by all variations except $6 \times 9 \mathrm{~m}$.

Table 4: Min. and max. mDF values (size width $x$ depth).

\begin{tabular}{|c|c|c|c|c|c|}
\hline & \multirow{2}{*}{$\begin{array}{c}\text { VT } \\
(\%)\end{array}$} & \multicolumn{2}{|c|}{ Stand. materials } & \multicolumn{2}{|c|}{ Imp. ref. materials } \\
\hline & & Min & Max & Min & Max \\
\hline \multirow{4}{*}{ 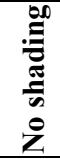 } & 63.5 & $2.16 \%$ & $3.93 \%$ & $2.7 \%$ & $4.91 \%$ \\
\hline & (s-e-w) & $6 \times 9 m$ & $7 \times 5 \mathrm{~m}$ & $6 \times 9 m$ & $7 \times 5 \mathrm{~m}$ \\
\hline & 73.3 & $2.54 \%$ & $4.61 \%$ & $3.16 \%$ & $5.64 \%$ \\
\hline & (n) & $6 \times 9 m$ & $9 \times 5 \mathrm{~m}$ & $6 \times 9 m$ & $7 \times 5 \mathrm{~m}$ \\
\hline \multirow{4}{*}{ : } & 63.5 & $1.42 \%$ & $2.46 \%$ & $1.74 \%$ & $3.07 \%$ \\
\hline & (s) & $8 \times 9 m$ & $7 \times 5 \mathrm{~m}$ & $6 \times 9 m$ & $9 \times 5 \mathrm{~m}$ \\
\hline & 70.7 & $1.56 \%$ & $2.77 \%$ & $1.98 \%$ & $3.45 \%$ \\
\hline & $(e-w)$ & $6 \times 9 m$ & $7 \times 5 \mathrm{~m}$ & $6 \times 9 m$ & $9 \times 5 \mathrm{~m}$ \\
\hline
\end{tabular}

\section{Spatial Daylight Autonomy simulation results}

Simulation results of sDA are presented and relation with $\mathrm{mDF}$ results is analysed. $\mathrm{mDF}$ results are presented for different orientations due to different glazing VT and shading combinations, as discussed in section Room parametric model, and to analyse relation with sDA.

For south orientation all 50 room variations without shading fulfil sDA requirement (Figure 5). For room with standard materials sDA varies from $61 \%$ of variation $7 \times 9 \mathrm{~m}$ to $99.9 \%$ of variation $6 \times 5 \mathrm{~m}, 7 \times 5 \mathrm{~m}$ and $8 \times 5 \mathrm{~m}$. Using improved reflectance materials $\mathrm{sDA}$ values range between $72.3 \%$ of variation $5 \times 9 \mathrm{~m}$ and $100 \%$ of all room variations with depth $5 \mathrm{~m}, 6 \mathrm{~m}$ and $7 \mathrm{~m}$ except variations $5 \times 7$ and $9 \times 7 \mathrm{~m}$.

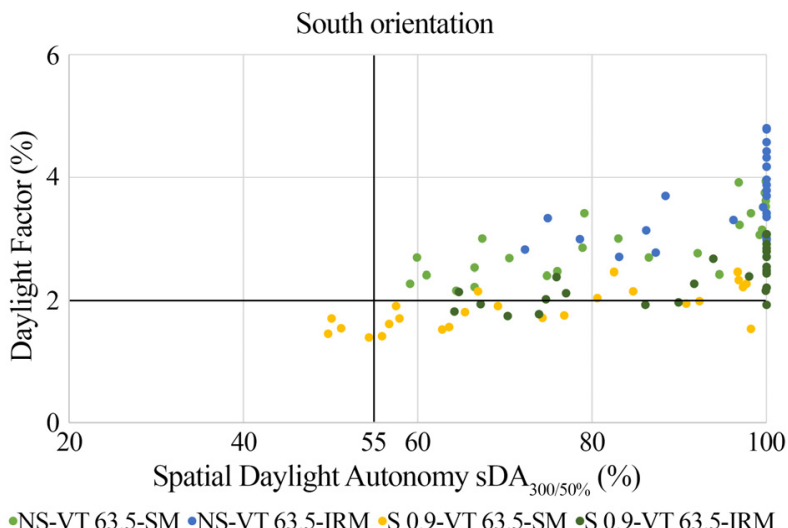

Figure 5: $m D F$ and $s D A$ for south orientation. In the lower-right sector variations fulfilling $s D A$ but not $m D F$.
For southward room with shading and standard materials sDA is fulfilled by all variations with depth $5 \mathrm{~m}, 6 \mathrm{~m}, 7 \mathrm{~m}$ and $8 \mathrm{~m}$ except $9 \times 8 \mathrm{~m}$. Minimum sDA is $49.7 \%$ of variation $5 \times 9 \mathrm{~m}$ and maximum is $97.7 \%$ of variation $8 \times 5 \mathrm{~m}$. All improved reflectance material cases fulfil sDA requirement with values from $64.2 \%$ of variation $5 \times 9 \mathrm{~m}$ to $100 \%$ of all cases with depth $5 \mathrm{~m}$ and $6 \mathrm{~m}$ except $9 \times 6 \mathrm{~m}$.

Results show that a total of $40 \%$ of southward orientation variations with shading fulfil sDA requirement but not mDF. (Figure 5). 52\% of variations with standard materials, i.e. variations $6 \times 6 \mathrm{~m}$ and $8 \times 6 \mathrm{~m}$, all those with depth $7 \mathrm{~m}, 8 \mathrm{~m}$ except $9 \times 8 \mathrm{~m}$, and variations $8 \times 9 \mathrm{~m}$ and $9 \times 9 \mathrm{~m} .28 \%$ of variations with improved reflectance materials, i.e. $6 \times 8 \mathrm{~m}, 8 \times 8 \mathrm{~m}$ and all those with depth $9 \mathrm{~m}$.

None of the south facing room variations fulfil ASE $1000 / 250 \leq 10 \%$ requirement, the minimum being $10.4 \%$ of variation $5 \times 9 \mathrm{~m}$ with shading and the maximum $45.4 \%$ of variation $8 \times 5 \mathrm{~m}$ without shading.

The majority of the eastward room variations without shading and with standard materials fulfil the sDA requirement (Figure 6). The variations not fulfilling are $9 \times 7 \mathrm{~m}$ and all those with depth $8 \mathrm{~m}$ and $9 \mathrm{~m}$ except $8 \times 8 \mathrm{~m}$ and $9 \times 9 \mathrm{~m}$. The maximum sDA value is $97.4 \%$ of variation $8 \times 5 \mathrm{~m}$. All the room variations without shading and with improved reflectance materials fulfil the sDA requirement with a range between $56.5 \%$ of variation $5 \times 9 \mathrm{~m}$ and $100 \%$ of all variations with depth $5 \mathrm{~m}$ except $5 \times 9 \mathrm{~m}$ and variations $6 \times 6 \mathrm{~m}$ and $8 \times 6 \mathrm{~m}$.

Less than half the east facing variations with shading and standard materials fulfil sDA requirement, i.e. all those with room depth $5 \mathrm{~m}, 6 \mathrm{~m}$ except $9 \times 6 \mathrm{~m}$ and variations $6 \times 7 \mathrm{~m}$ and $8 \times 7 \mathrm{~m}$. Except variations $9 \times 8 \mathrm{~m}, 5 \times 9 \mathrm{~m}$ and $7 \times 9 \mathrm{~m}$ the majority of the cases with improved reflectance materials fulfil the requirement between the range $56.2 \%$ of case $6 \times 9 \mathrm{~m}$ and $100 \%$ of cases $5-8 \times 5 \mathrm{~m}$ (width $\mathrm{x}$ depth). A number of east facing room variations fulfil $\mathrm{mDF}$ but not sDA (Figure 6). Without shading and with standard materials $36 \%$ of variations, i.e. $9 \times 7 \mathrm{~m}$, all of those with depth $8 \mathrm{~m}$ except $8 \times 8 \mathrm{~m}$ and $9 \mathrm{~m}$ except $9 \times 9 \mathrm{~m}$. With shading and standard materials variations $9 \times 6 \mathrm{~m}, 5 \times 7 \mathrm{~m}$, $7 \times 7 \mathrm{~m}$ and $9 \times 7 \mathrm{~m}$. With shading and improved reflectance material variations $9 \times 8 \mathrm{~m}, 5 \times 9 \mathrm{~m}$ and $7 \times 9 \mathrm{~m}$. Among all cases three fulfil sDA but not mDF.

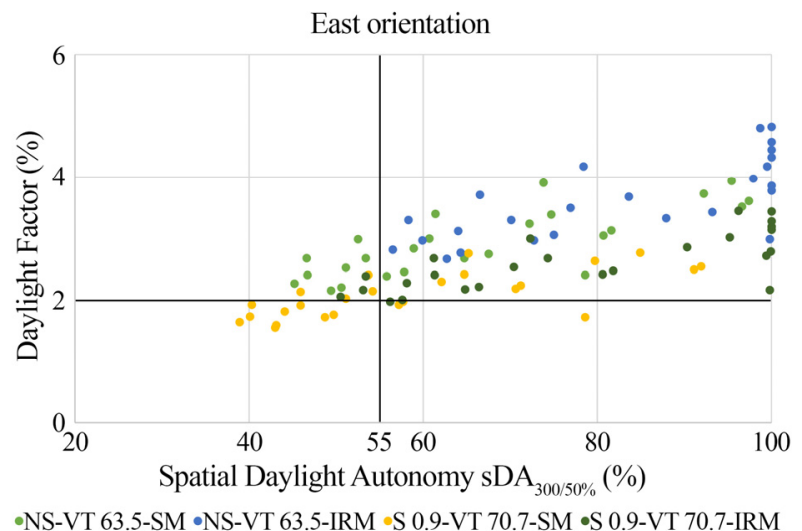

Figure 6: $\mathrm{mDF}$ and $\mathrm{s} A \mathrm{~A}$ for east orientation. In the upper-left sector variations fulfilling $m D F$ but not $s D A$. 
Conversely to south facing room variations all of the 50 analysed east facing variations fulfil the ASE 1000/250 $\leq 10 \%$ requirement. All of the calculated ASE values are in the small range between $0 \%$ and $1.8 \%$ for the variations without shading and between $0 \%$ and $0.2 \%$ for the variations with shading.

For the north orientation are analysed room variations without shading, with standard and improved reflectance materials, but not variations with shading, for a total of 50. The reason is that rooms facing north at Tallinn latitude and during the occupied hours rarely have direct solar access and do not have overheating problems. This is confirmed by the Annual Sunlight Exposure value 0\% for all the 50 variations without shading.

For northward room cases with standard materials SDA is fulfilled by all the variations with depth $5 \mathrm{~m}$ and $6 \mathrm{~m}$ except $9 \times 6 \mathrm{~m}$ (width $\mathrm{x}$ depth) and by variations $6 \times 7 \mathrm{~m}$ and $8 \times 7 \mathrm{~m}$ (Figure 7). When improved materials are used sDA is fulfilled by all room variations with depth $5 \mathrm{~m}, 6 \mathrm{~m}, 7 \mathrm{~m}$, $8 \mathrm{~m}$ except $5 \times 8 \mathrm{~m}$ and $9 \times 8 \mathrm{~m}$ and by the two largest width variations of room depth $9 \mathrm{~m}$.

Also for north orientation a number of variations fulfil $\mathrm{mDF}$ but not sDA requirement (Figure 7). 56\% of variations with standard materials, i.e. variation $9 \times 6 \mathrm{~m}$, all variations with room depth $7 \mathrm{~m}$ except $6 \times 7 \mathrm{~m}$ and $8 \times 7 \mathrm{~m}$, and all variations with room depth $8 \mathrm{~m}$ and $9 \mathrm{~m}$. When finishing materials with improved reflection are used $20 \%$ of variations fulfil $\mathrm{mDF}$ but not $\mathrm{sDA}$, i.e. variations $5 \times 8 \mathrm{~m}$, $9 \times 8 m$ and all variations with room depth $9 \mathrm{~m}$ except $8 \times 9 \mathrm{~m}$ and $9 \times 9 \mathrm{~m}$.

Daylight performance of westward orientation variations for Spatial Daylight Autonomy 300/50\% $\geq 55 \%$ are consistent with east facing room cases inasmuch a number of variations fulfil $\mathrm{mDF}$ but not $\mathrm{sDA}$ requirement, being the westward cases in a larger number comparing those of the opposite façade (Figure 8).

For west facing variations without shading and standard materials sDA is fulfilled by all room cases with depth $5 \mathrm{~m}, 6 \mathrm{~m}$ except $9 \mathrm{x} 6 \mathrm{~m}$ (width $\mathrm{x}$ depth) and cases with depth $7 \mathrm{~m}$ except variations $6 \times 7 \mathrm{~m}$ and $8 \times 7 \mathrm{~m}$. When improved reflectance materials are used, in association with no external obstruction provided by shading device, sDA requirement is fulfilled by the majority of room cases.

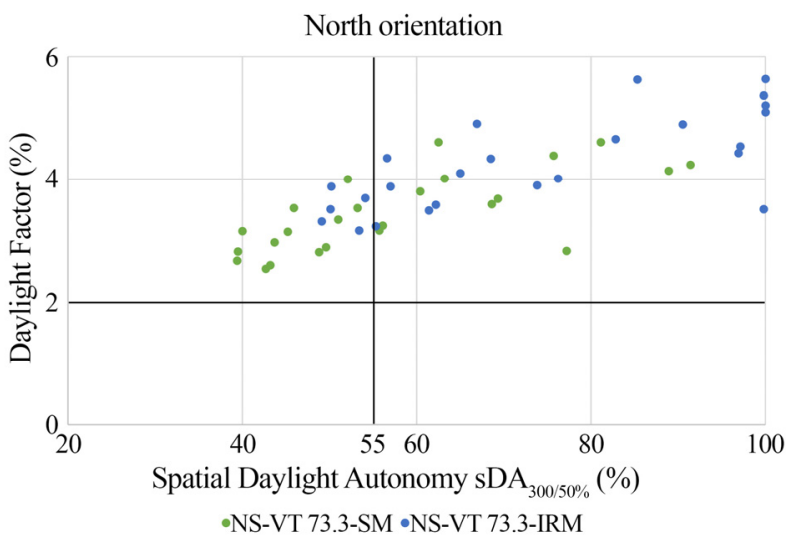

Figure 7: $m D F$ and $s D A$ for north orientation. In the upper-left sector variations fulfilling $m D F$ but not $s D A$.
All room variations with depth $5 \mathrm{~m}, 6 \mathrm{~m}, 7 \mathrm{~m}$ and $8 \mathrm{~m}$ except case $5 \times 8 m$ fulfil sDA requirement.

For westward variations with shading and standard materials few cases fulfil sDA requirement, i.e. all room cases with depth $5 \mathrm{~m}$ except $9 \times 5 \mathrm{~m}$, and among cases with depth $6 \mathrm{~m}$ those with width $6 \mathrm{~m}, 7 \mathrm{~m}$ and $8 \mathrm{~m}$. The majority of variations with shading and with improved reflectance materials fulfil sDA requirement. Those not fulfilling are variation $9 \times 7 \mathrm{~m}$ and all those with room depth $8 \mathrm{~m}$ and $9 \mathrm{~m}$. Among all the room orientations, the west facings are those with the highest number of variations which fulfil mean Daylight Factor $\geq 2 \%$ requirement but not Spatial Daylight Autonomy 300/50\% $\geq 55 \%$ (Figure 8). For variations without shading and standard materials $56 \%$ fulfil $\mathrm{mDF}$ but not $\mathrm{sDA}$ and $28 \%$ among variations without shading and improved reflectance materials. Also $28 \%$ of variations among those with shading and with standard materials fulfil $\mathrm{mDF}$ but not $\mathrm{sDA}$ and $40 \%$ for the cases with shading and improved materials.

Annual Sunlight Exposure for west orientation variations is consistent with eastward ones being the results for all the cases ASE 0\%. This way daylight predictions state that no extended in time glare effects are expected on both east and west orientations as well as for north one.

\section{Summary of daylight metrics results comparison}

Taking into account all the variations the number of cases for which $\mathrm{mDF}$ is fulfilled but $\mathrm{sDA}$ is not outnumber the cases for which $\mathrm{SDA}$ is fulfilled but $\mathrm{mDF}$ is not (Table 5).

Table 5: Variations fulfilling only $m D F$ or $s D A$.

\begin{tabular}{|c|c|c|}
\hline & mDF $\boldsymbol{~}$ - SDA $\mathbf{X}$ & SDA $\boldsymbol{~}$ - mDF $\mathbf{X}$ \\
\hline South & - & $20 \%$ \\
\hline East & $16 \%$ & $3 \%$ \\
\hline North & $38 \%$ & - \\
\hline West & $38 \%$ & - \\
\hline
\end{tabular}

For south facing room variations 20 cases out of 100 fulfil sDA but not mDF. For eastward room variations 16 and 3 cases out of 100 fulfil mDF but not SDA and sDA but not $\mathrm{mDF}$ respectively. For north facing room cases 19 out of 50 and for westward room variations 38 out of 100 fulfil $\mathrm{mDF}$ but not sDA. Daylight metrics result differences are discussed further in section Discussion.

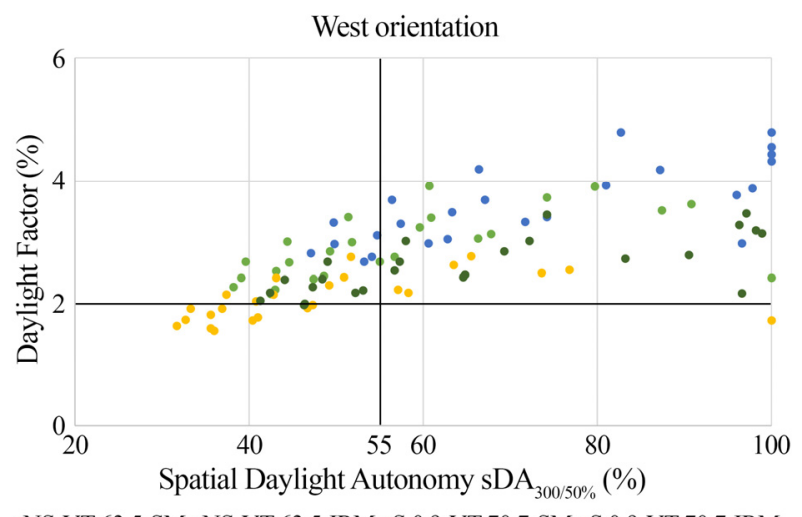

•NS-VT 63.5-SM •NS-VT 63.5-IRM •S 0.9-VT 70.7-SM •S 0.9-VT 70.7-IRM

Figure 8: $m D F$ and $s D A$ for west orientation. In the upper-left sector variations fulfilling $\mathrm{mDF}$ but not $s D A$. 


\section{Overheating simulation results}

Results of overheating simulations are presented and relation with $\mathrm{mDF}$ is analysed for room combinations only with standard materials. Alike for $\mathrm{sDA}, \mathrm{mDF}$ results are presented for different orientations due to different glazing VT and use of shading, and to analyse relation with overheating. Relation with ASE is presented in next section Discussion.

For south orientation without shading all rooms exceed overheating limit and fulfil the $\mathrm{mDF}$ requirement (Figure 9). Classrooms with $5 \mathrm{~m}$ depth are overheated up to $190^{\circ} \mathrm{C} \cdot \mathrm{h}$ and have minimum $\mathrm{mDF} 2.16 \%$. Adding shading helps to prevent all the rooms from overheating, but larger room depth reduces significantly daylighting. With the use of shading overheating is between $30^{\circ} \mathrm{C} \cdot \mathrm{h}$ and $45^{\circ} \mathrm{C} \cdot \mathrm{h}$ and $\mathrm{mDF}$ ranges between $1.42 \%$ and $2.46 \%$.

East orientation results are more spread out. Without shading, room variations with depth $5 \mathrm{~m}, 6 \mathrm{~m}$ and $7 \mathrm{~m}$ are overheated up to $175^{\circ} \mathrm{C} \cdot \mathrm{h}$, and all meet the daylight requirement with minimum $\mathrm{mDF} 2.16 \%$ (same of south). If for both east and west orientations shading is added and façade glass g-value increases from 0.35 to 0.42 , room variations divide into three sectors (Figure 10). Rooms with $5 \mathrm{~m}$ depth are overheated up to $120^{\circ} \mathrm{C} \cdot \mathrm{h}$ as horizontal shading can reduce only partially overheating of small depth rooms and present a minimum $\mathrm{mDF}$ of $2.5 \%$.

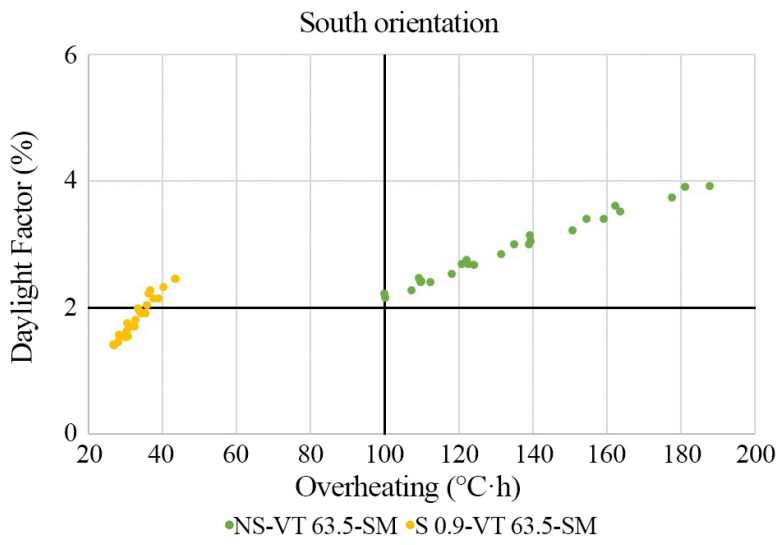

Figure 9: $m D F$ and ${ }^{\circ} \mathrm{C} \cdot h$ plot for south orientation. Upper-right sector variations fulfil $\mathrm{mDF}$ but not ${ }^{\circ} \mathrm{C} \cdot \mathrm{h}$.

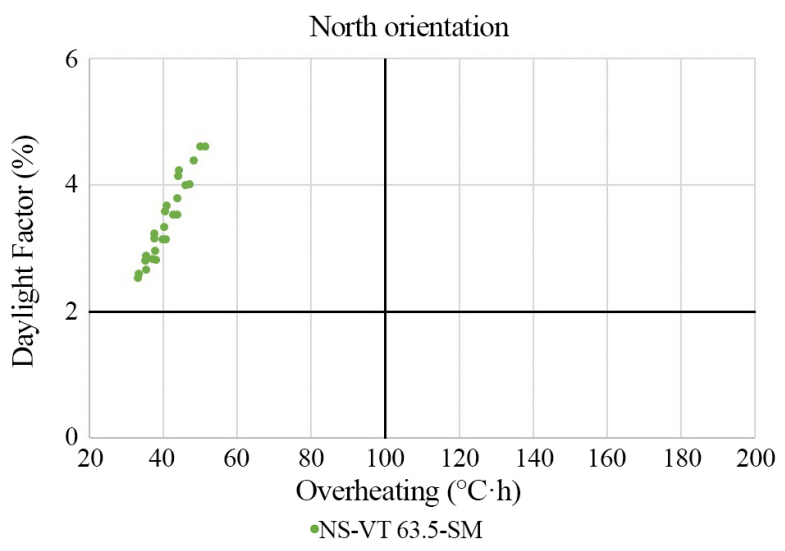

Figure 11: $\mathrm{mDF}$ and ${ }^{\circ} \mathrm{C} \cdot \mathrm{h}$ plot for north orientation. Upper-left sector variations fulfil both $\mathrm{mDF}$ and ${ }^{\circ} \mathrm{C} \cdot h$.
North façade overheating is analysed only without shading as it is not necessary to block direct sunlight in north orientation. All the rooms meet both overheating and daylight requirements (Figure 11). Overheating is between $33^{\circ} \mathrm{C} \cdot \mathrm{h}$ and $51^{\circ} \mathrm{C} \cdot \mathrm{h} . \mathrm{m}$. Meanwhile, $\mathrm{mDF}$ decreases steadily from $4.61 \%$ to $2.54 \%$ as room depth increases. For north façade, higher glass g-value 0.54 is used to allow more natural lighting entering classrooms.

For West façade without shading $5 \mathrm{~m}$ depth room variations are overheating up to $117^{\circ} \mathrm{C} \cdot \mathrm{h}$ (Figure 12), and all rooms meet the daylight requirement with $\mathrm{mDF}$ values between $2.16 \%$ and $3.93 \%$ (same of south and east). Adding horizontal shading and optimized g-value of 0.42 , similarly to east, overheating is under control with values between $47^{\circ} \mathrm{C} \cdot \mathrm{h}$ and $82^{\circ} \mathrm{C} \cdot \mathrm{h}$. In these cases, $\mathrm{mDF}$ ranges between $1.56 \%$ and $2.77 \%$.

Results show that overheating is not a problem for north orientations. Higher g-value (solar factor) and shading may be used to reduce overheating for other orientations. For south façade, overheating is avoided by adding horizontal shading, but extra shading may lead to less daylight for classrooms with larger depth. For both east and west orientations horizontal shading may help to some limits as simulation results are more outspreaded. Figure 10 and 12 show that it is crucial for façade design to take both $\mathrm{mDF}$ and ${ }^{\circ} \mathrm{C} \cdot \mathrm{h}$ parameters into account.

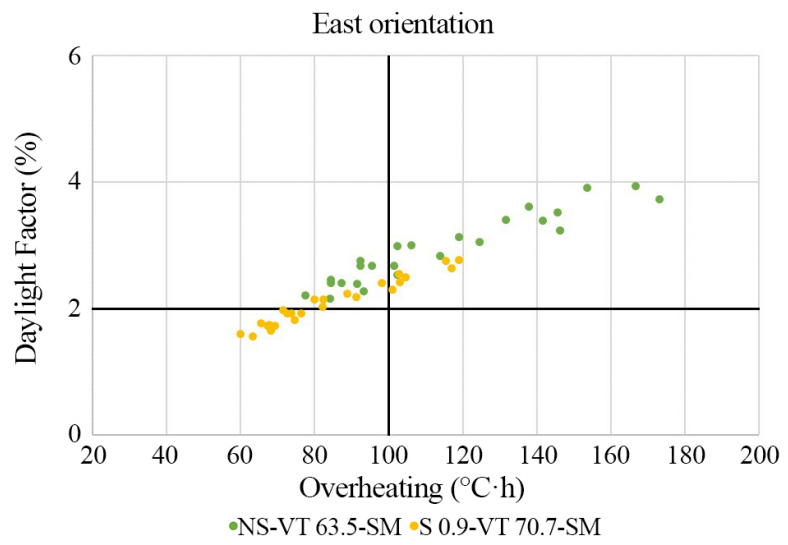

Figure 10: $\mathrm{mDF}$ and ${ }^{\circ} \mathrm{C} \cdot \mathrm{h}$ plot for east orientation. Upper-right sector variations fulfil $m D F$ but not ${ }^{\circ} \mathrm{C} \cdot h$.

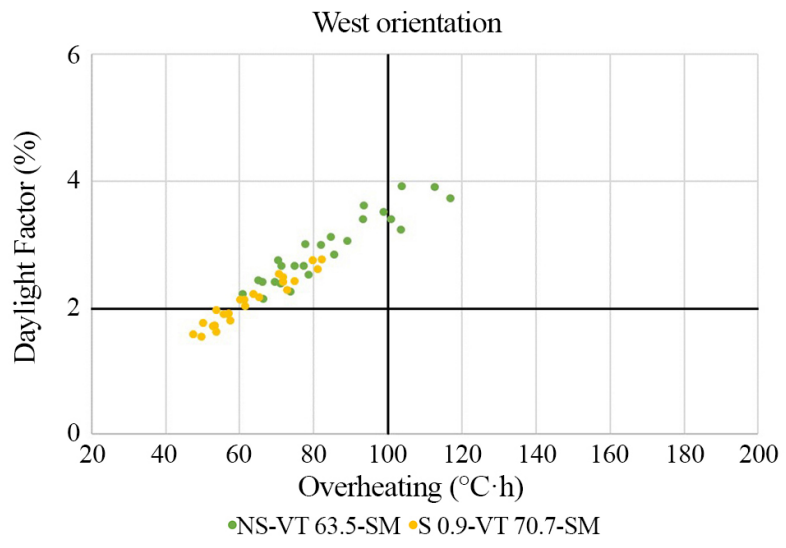

Figure 12: $\mathrm{mDF}$ and ${ }^{\circ} \mathrm{C} \cdot \mathrm{h}$ plot for west orientation. Upper-left sector variations fulfil both $\mathrm{mDF}$ and ${ }^{\circ} \mathrm{C} \cdot h$. 


\section{Discussion}

Evidence show the inconsistencies between mean Daylight Factor and Spatial Daylight Autonomy results for a large quantity of room variations for the analysed educational type of building and for the location of Tallinn.

As presented in Table 5 for south facing classrooms $20 \%$ of variations fulfil sDA but not $\mathrm{mDF}$. This doesn't constitute an issue and doesn't prevent designing rooms with appropriate quantity of daylight being sDA a more reliable daylight availability metric than DF. Since for all the other room variations the results match, if a classroom fulfils the minimum $\mathrm{mDF} 2 \%$ requirement of the Estonian daylight standard, it automatically fulfils the sDA requirement $300 / 50 \% \geq 55 \%$.

Except for a small quantity (3\%) of classroom variations with east orientation which fulfils sDA but not $\mathrm{mDF}$, the majority of the cases presenting inconsistencies of results between the two metrics fulfil mDF but not sDA. These are $16 \%, 38 \%$ and $38 \%$ of the room variations respectively with orientation east, north and west. This constitutes an issue. Being Spatial Daylight Autonomy a more reliable metric in predicting daylight availability, using Daylight Factor as required by the Estonian daylight standard do not guarantee the design of classrooms with appropriate quantity of natural light for all building orientations in Tallinn.

These findings show the weakness of Daylight Factor, which is a static and outdated metric, instead than other more recent and advanced metrics which take location climate and building orientation into account. In case of using DF the authors recommend to use different minimum requirements for different orientations. As the results of this study show minimum mDF should be higher than $2 \%$ for orientations toward east, north and west for the analysed type of room and location.

The reason of a smaller daylight availability towards east and west than south is due to sun angles with the room window during the occupied hours. During morning (east orientation) from 8am to noon and afternoon (west orientation) from noon to $4 \mathrm{pm}$ sun light enters the classroom with a large angle of incidence (angle between the sun and a line perpendicular to the façade) for most of the time. Whereas for south orientation sun light enters the classroom with a small angle of incidence, hence with a larger solar radiation, for a large quantity of occupied hours. Additionally, the larger daylight availability toward east than west (smaller number of variations that fulfil $\mathrm{mDF}$ but not sDA), though the operating hours are the same (approx. 4), is due to solar time shift in spring.

The finding of the weakness of Daylight Factor metric in relation to the analysed educational type of building can be assumed also for other types of buildings and interiors with similar operating hours such as office and commercial. For the same reason the finding of this study cannot be extended also to residential dwellings which are considered to be occupied for the entire day. For this building type the appropriateness of Daylight Factor metric in Estonia need to be verified.

\section{Conclusion}

The main aim of the present study is to analyse the validity of the minimum value of mean Daylight Factor for educational building classrooms as required by the Estonian standard "Daylight in dwellings and offices". Daylight availability for a classroom model located in the city of Tallinn using the minimum requirement of $\mathrm{mDF} \geq$ $2 \%$ is tested against results of more reliable climate-based daylight simulations performed using the approved method Spatial Daylight Autonomy 300/50\% $\geq 55 \%$.

Additionally, potential glare and overheating risk, both due to excessive direct solar access, are assessed. The first through the metric Annual Sunlight Exposure 1000/250 $10 \%$ and the latter in relation to Estonian energy efficiency requirements.

The case study of a classroom limits the analysis to one building type, nevertheless assumptions can be extended to other type of buildings. A large number of room variations are analysed, different for size, proportions, orientation, use of shading and material characteristics.

Results show that Daylight Factor analysis in a large number of cases for south orientation variations underestimate and for a larger number of cases toward east, north and west overestimates daylight potentialities for the analysed type of room and location. Findings can be extended to similar building types such as office and commercial which are occupied during the central hours of the $24 \mathrm{~h}$ day.

On the basis of the findings it is recommended to use more reliable climate-based simulations and metrics to assess more accurately daylight availability in building interiors. A revision of the actual Estonian daylight standard is also recommended and the use of different minimum requirements for different orientations suggested with values of minimum $\mathrm{mDF}$ larger than $2 \%$ for east, north and west orientations.

The use of improved reflectance materials, in opposition to standard materials as recommended by regulations and simulation good norms, improving daylight availability in building interiors, reduces the number of simulated cases that fulfil one requirement but not the other hence increases the reliability of Daylight Factor metric. Additionally, improved reflectance materials used in this study have properties closer to actual common interior finishing than the recommended standard materials.

According to climate based dynamic simulation results maximum depth for properly daylight classrooms varies depending on orientation, use of shading and material characteristics. Considering the $80 \%$ of floor area used in the study, for classroom facing south without shading all the room depths with standard and improved reflectance materials permit properly daylit classrooms. Using shading and standard materials up to $8 \mathrm{~m}$ depth classrooms and all those with improved reflectance materials are properly daylit. Classrooms facing east without shading and standard materials are properly daylight up to $7 \mathrm{~m}$ depth, and all of those without shading and improved reflectance materials. With shading and standard 
materials room depth required for daylit classrooms facing east is maximum $6 \mathrm{~m}$ which increases to $8 \mathrm{~m}$ using improved reflectance materials. Classrooms facing north without shading are properly daylit up to $6 \mathrm{~m}$ depth in case standard materials are used and $8 \mathrm{~m}$ in case improved reflectance materials are used. West orientation classrooms without shading with depth up to $6 \mathrm{~m}$ are properly daylit in case of standard materials and up to $8 \mathrm{~m}$ in case of improved reflectance materials. In case shading is used toward west, well daylit classrooms are obtained only with room depth $5 \mathrm{~m}$ with standard materials and up to room depth $7 \mathrm{~m}$ for improved reflectance materials. The difference of depth for properly daylit classrooms toward east and west is due to solar time shift in spring.

Results show as well that potential glare needs to be taken into account in the design of envelope and glazing areas of south facing classrooms. For the other orientations glare probability is small for this type of building and it can be controlled simply by a wise interior desk layout.

Overheating simulation results indicate that room dimensions work the opposite way for $\mathrm{mDF}$ and ${ }^{\circ} \mathrm{C} \cdot \mathrm{h}$. Results show clearly that designing classrooms without room conditioning units or cooled supply air requires careful combined analyses of both $\mathrm{mDF}$ and ${ }^{\circ} \mathrm{C} \cdot \mathrm{h}$ requirements in order to find quite limited and not obvious solutions satisfying both criteria.

Future development of the presented research is to investigate reliability of Daylight Factor requirement of the Estonian regulation through climate-based daylight analysis and overheating simulations for different existing school buildings. Using real classrooms of specific size, orientations and material properties will expand the dataset allowing more reliable evaluations and will permit to test daylight assumptions against specific building use.

\section{Acknowledgements}

The research has been supported by the European Regional Development Fund grant ZEBE 20142020.4.01.15-0016.

\section{References}

Annesi, C. and Annesi-Maesano I. (2016). Impact of Lighting on School Performance in European Classrooms. Proceedings from CLIMA 2016. Aalborg (DK), 22-25 May 2016.

De Luca, F., Dogan, T. and Kurnitski, J. (2018). Methodology for determining fenestration ranges for daylight and energy efficiency in Estonia. Proceedings from Symposium on Simulation for Architecture and Urban Design 2018 (SimAUD). Delft (NL), 4-7 June 2018.

EQUA. (2019). IDA Indoor Climate and Energy 4.8: Equa Simulations AB. www.equa.se

Estonian Centre for Standardization (2015). Daylight in Dwellings and Offices. 894:2008/A2:2015.

Estonian Government (2019). Energy efficiency minimum requirements for buildings. Annex 58, RT I, 18.01.2019, 12 .
Estonian Government (2019). Energy efficiency calculation methods for buidlings Annex 63, RT I, 13.12.2018, 14 .

Heschong, L., Wright, R.L. and Okura, S. (2002). Daylighting Impacts on Human Performance in School. Journal of the Illuminating Engineering Society 31(2), 101-114.

Illuminating Engineering Society (2013). Approved Method: IES Spatial Daylight Autonomy (sDA) and Annual Sunlight Exposure (ASE).

Johnsen, K. and Watkins, R. (2010). Daylighting in Buildings. Energy Conservation in Buildings \& Community Systems \& Solar Heating and Cooling Programmes. AECOM, Birmingham (UK).

Lockley, S.W. (2009). Circadian Rhythms: Influence of Light in Humans. In Squire L.R. Encyclopedia of Neuroscience, vol. 2, Academic Press, Cambridge (USA), 971-988.

Nabil, A. and Mardaljevic, J. (2006). Useful Daylight Illuminances: A Replacement for Daylight Factors. Energy and Buildings 38(7), 905-913.

Reinhart, C.F. and Walkenhorst, O. (2001). Validation of dynamic RADIANCE-based daylight simulations for a test office with external blinds, Energy and Buildings 33, 683-697.

Reinhart C.F., Mardaljevic J., and Rogers, Z. (2006). Dynamic Daylight Performance Metrics for Sustainable Building Design, Leukos 3(1), 7-31.

Reinhart, C.F. and Lo Verso, V.M. (2010). A Rules of Thumb Based Design Sequence for Diffuse Daylight. Lighting Research and Technology 42(1), 7-32.

Reinhart, C.F. (2014). Daylighting Handbook I. Fundamentals. Designing with the Sun. Building Technology Press, Cambridge (USA).

Robert McNeel \& Associates (2019). Grasshopper. www.grasshopper3d.com

Solemma LLC. (2019). DIVA. www.solemma.net

Voll, H., De Luca, F. and Pavlovas, V. (2016). Analysis of the insolation criteria for nearly-zero energy buildings in Estonia. Science and Technology for the Built Environment 22(7), 939-950.

Voll, H., Thalfeldt, M., De Luca, F., Kurnitski, J. and Olesk, T. (2016). Urban planning principles of nearly zero-energy residential buildings in Estonia. Management of Environmental Quality: An International Journal 27(6), 634-648.

Waldram, J.P. (1923). The Natural and Artificial Lighting of Buildings. Journal of the Royal Institute of British Architects 33(13), 405-426 and 441-446.

Ward, G.J. (1994). The RADIANCE Lighting Simulation and Rendering System. Proceedings from SIGGRAPH 1994, Orlando (USA), 24-29 July. 